\title{
Additions to the Marine Algal (Seaweed) Flora of the Azores
}

\author{
I. Tittley ${ }^{\mathrm{a} *}$, A. I. Neto ${ }^{\mathrm{b}}$, W. F. Farnham ${ }^{\mathrm{c}}$ and M. I. Parente \\ a The Natural History Museum, Cromwell Road, London SW7 5BD, U. K. \\ b Departamento de Biologia, Universidade dos Açores, Rua da Mae de Deus, PT-9500 Ponta Delgada, Azores, Portugal \\ c Institute of Marine Sciences, University of Portsmouth, Portsmouth PO49 9LY, U. K. \\ * Corresponding author
}

Ten species of benthic marine algae, new distribution records for the Azores achipelago, are itemised; two other species records (Heterosiphonia crispella and Laminaria ochroleuca) are confirmed for the islands. Six species (Bryopsis pennata, Cottoniella filamentosa, Dasya baillouviana, Feldmannia paradoxa, Heterosiphonia crispella and Lomentaria clavellosa) show an amphi-Atlantic distribution pattern; four (Bonnemaisonia asparagoides, Laminaria ochroleuca, Pterosphonia ardreana and Stylonema cornu-cervi) show a European-AfricanMediterranean distribution pattern. The occurrence of Dudresnaya crassa, a western Atlantic warm-water species, represents an extension of its known distributional range to the east. An Ahnfeltiopsis was found which resembled $A$. intermedia, a species that occurs in the Atlantic Ocean to the south of the Azores.

\section{Introduction}

The Azores is an archipelago of nine islands $1200 \mathrm{~km}$ west of mainland Portugal towards the centre of the Atlantic Ocean. Its geographical isolation from mainland Europe is probably the reason for few early studies in the marine flora, although records do go back a century and a half. During the past decade there has been a resurgence of algal interest resulting in publication of a comprehensive algal checklist (Neto 1994) based on information derived from a series of field expeditions throughout the archipelago (e. g. Fralick and Hehre 1990, Fredericq et al. 1992, Neto, 1992, Athanasiadis and Tittley 1994, Neto and Tittley 1995, Tittley and Neto 1994, 1995). The present paper, Tittley et al. (1998), and Parente and Neto (2000) add new species records to the marine flora of the Azores.

\section{Materials and Methods}

The algae were collected mainly during 'Project Praxis: Biodiversity in the Archipelago of the Azores' field expeditions (1996-8) from sub-tidal locations at São Vicente, Capelas and Ribeirinha on the north coast of São Miguel Island, and at Ponta Delgada, São Roque, Caloura and Lagoa on the south coast. We also refer to specimens obtained in earlier expeditions (Faial, Chelsea College expedition, 1965; Formigas, CANCAP expedition, 1981; Formigas, Universidade dos Açores expedition, 1991). Material acquired was either fixed in 5\% Formalin seawater or pressed and air dried. When necessary microscope slide preparations were made by staining material with aniline blue and permanently mounting using Karo corn syrup. Specimens are deposited at the Uni- versity of the Azores (UA) and the Natural History Museum, London (BM).

\section{Results: Systematic Account}

Chlorophycota, Bryopsidophyceae

Bryopsidales, Bryopsidaceae

Bryopsis pennata Lamouroux

Full description and illustration in Taylor 1960, p. 132, pl. 9, fig. 12 .

Occurs as a small tufted plant with sparingly divided erect filaments which grow to $40 \mathrm{~mm}$ high. Distichous branchlets of uniform length give the feathery frond a linear-lanceolate or oblong shape. Fertile material has not been observed in the Azores.

Occasional tufts grew among a turf of algae at sublittoral levels (to $20 \mathrm{~m}$ depth).

Bryopsis pennata is the type species of its genus and was first described from the Antilles in the Caribbean Sea (Lamouroux 1809). It has an amphi-Atlantic distribution occurring in America from Florida to North Carolina, Bermuda, the Azores, and sporadically in southern Europe (France, Portugal) and Africa (Ivory Coast).

Specimens examined: São Miguel I., Caloura (Porto), 19. 07. 1997, SMG-97-227 (UA); São Miguel I., São Vicente, 21. 07. 1997, SMG-97-252 (UA).

\section{Chromophycota, Phaeophyceae (Fucophyceae)}

Ectocarpales, Ectocarpaceae

Feldmannia paradoxa (Montagne) Hamel

Full descriptions and illustrations in Cardinal 1964, p. 55, fig. 30 [as F. simplex (P. Crouan et $\mathrm{H}$. Crouan) 
Hamel], and Hamel 1931-1939, p. 50, fig. 15 (as Ectocarpus simplex $\mathrm{P}$. Crouan et $\mathrm{H}$. Crouan).

Synonym: Feldmannia simplex (P. Crouan et $\mathrm{H}$. Crouan) Hamel.

In the Azores it is a uniseriate filamentous plant which grows as an epiphyte on Codium elisabethae O. C. Schmidt. Although filaments grow among the utricles of Codium they also form a felt $1-5 \mathrm{~mm}$ high over the surface. Fertile material has not been observed in the Azores.

Feldmannia paradoxa occurred rarely at sublittoral levels to $10 \mathrm{~m}$ depth.

Feldmannia paradoxa is an amphi-Atlantic species which occurs widely in Europe from Scotland and the Netherlands to the Mediterranean Sea, Azores and Canaries. It also occurs in tropical America and coldtemperate Quebec.

Specimens examined: São Miguel I., São Vicente, 16. 09. 1998, SMG-98-1186 (UA).

Laminariales, Laminariaceae

Laminaria ochroleuca De la Pylaie

Full description in Hamel 1931-1939, p. 302, fig. $51 \mathrm{D}$.

The Azorean plants grow to only $1 \mathrm{~m}$ high, although many were smaller (Fig. 1). The thallus comprises a small fibrous basal system with haptera, a smooth stipe (to $230 \mathrm{~mm}$ long) and undivided or divided fronds. Trumpet cells are clearly visible in the medulla of the stipe. Fertile material has not been observed.

Laminaria ochroleuca, noted by Neto (1994) to be of uncertain occurrence in the archipelago, occurs in deep water $(25-37 \mathrm{~m})$, and is extremely rare in the Azores known from the Formigas Islets only.

The species is widespread in the warm-temperate and subtropical eastern Atlantic Ocean (from southern England to Western Sahara, and the Mediterranean Sea). The Azores represents the western limit of its distributional range.

Specimens examined: Formigas Islets, 02. 07. 1991, FOR-91-39; Formigas Islets, 27.05. 1981, CANCAP5-4527 [L-989.009 345]; Formigas Islets, 27. 05. 1981, CANCAP5-4527 [L-989.009 346].

\section{Rhodophycota, Bangiophycideae}

Porphyridiales, Goniotrichaceae

\section{Stylonema cornu-cervi Reinsch}

Full description and illustration in Hamel 1924, p. 450, fig. 6 [as Goniotrichum cornu-cervi (Reinsch) Hauck].

This is a small filamentous, reddish-violet epiphyte with cells irregularly placed in two to many rows in a gelatinous sheath. Cells are polygonal 5-12 m diameter. Azorean material was not branched.

The species grew epiphytic on Chaetomorpha at sublittoral levels ( $4-8 \mathrm{~m}$ depth) and was rare.
Stylonema cornu-cervi has been reported sporadically in the eastern North Atlantic Ocean (England, France, Spain and Madeira) and also the Mediterranean Sea.

Specimens examined: São Miguel I., Lagoa 18.09. 1998, SMG-98-1200a (UA).

\section{Florideophycideae}

Nemaliales, Bonnemaisoniaceae

Bonnemaisonia asparagoides (Woodward) C. Agardh

Full description and illustration in Dixon and Irvine 1977, p. 155, fig. 58.

Erect plants grow to $50 \mathrm{~mm}$ high with distichous and opposite branching but unequal and alternate development in each pair. Cystocarps are elongate (B. asparagoides is indistinguishable from B. clavata Hamel when sterile). Tetrasporangial plants form a prostrate crust not seen in the Azores.

Plants grew on rocks at sublittoral levels to $18 \mathrm{~m}$ depth and were rare.

Bonnemaisonia asparagoides occurs in temperate waters in the eastern North Atlantic Ocean (Scotland to Morocco) and in the Mediterranean Sea.

Specimens examined: São Miguel I., São Roque, 11. 07. 1996, SMG-96-107 (UA); São Miguel I., Ponta Delgada (Moaçor), 12.07. 1996, SMG-139 (UA).

\section{Gigartinales, Dumontiaceae}

\section{Dudresnaya crassa Howe}

Full descriptions and illustrations in Howe 1905, p. 572 , p. 28 , 29, figs. $12-26$, Taylor 1961 , p. 280 , figs. 5-21, Schneider and Searles 1973, p. 11, fig. 3A, and Eiseman and Norris 1981, p. 187.

Plants are erect, terete, gelatinous, vermiform, reddish-brown in colour and they grow to $105 \mathrm{~mm}$ high (Fig. 2). A $2-3 \mathrm{~mm}$ wide main axis bears irregular branching, branches are 1-2 mm wide, occasionally with annular constrictions. The main axial filament is visible after squashing the plant but is often obscured by lateral filaments. Rhizoids that surround the axial filament do not give rise to cortical lateral filaments. The distal cortical cells are cylindrical. Fertile plants have not been observed in the Azores.

The species grew on rocks at sub-littoral levels (to $18 \mathrm{~m}$ depth) and was sporadic in occurrence.

Dudresnaya crassa was previously known only from tropical and subtropical western Atlantic Ocean (from the Caribbean to North Carolina) and was first described from Bermuda. This occurrence represents an eastern extension of its distributional range.

Specimens examined: São Miguel I., Ponta Delgada (Moaçor), 12. .07. 1996, SMG-96-145 (UA). 
Phyllophoraceae

Ahnfeltiopsis c. f. intermedia (Kylin) Stegenga, Bolton et Anderson

Full description in Stegenga et al. 1997, p. 343, pl. 123, fig. 5.
Occurs as small wiry plants (Fig. 4). Fronds are 20-30 $\mathrm{mm}$ high, fronds irregularly, dichotomously branched and apically terete but flattened elsewhere (0.25-1 $\mathrm{mm}$ across). Cystocarps are immersed in the thallus (Fig. 4).
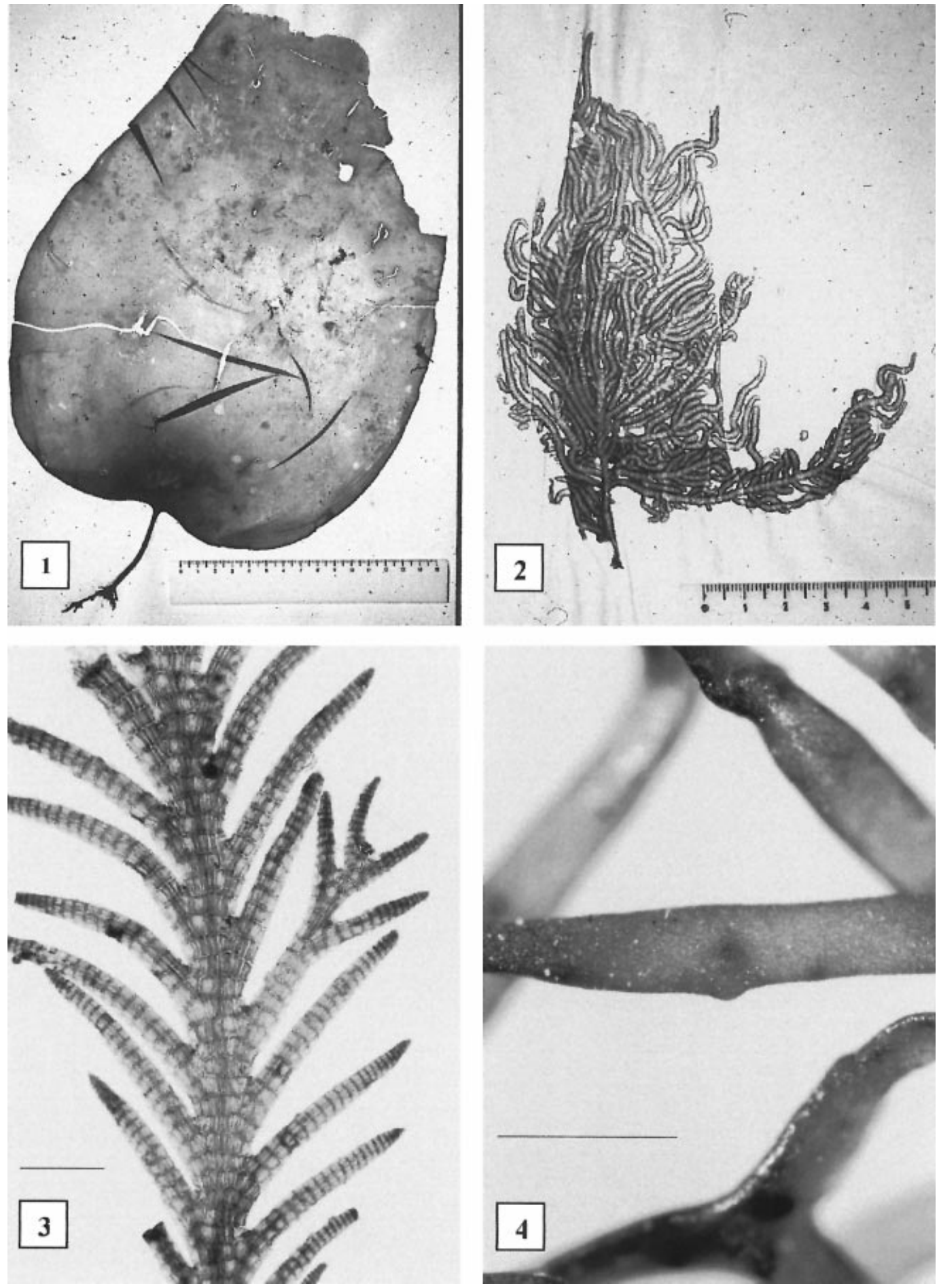

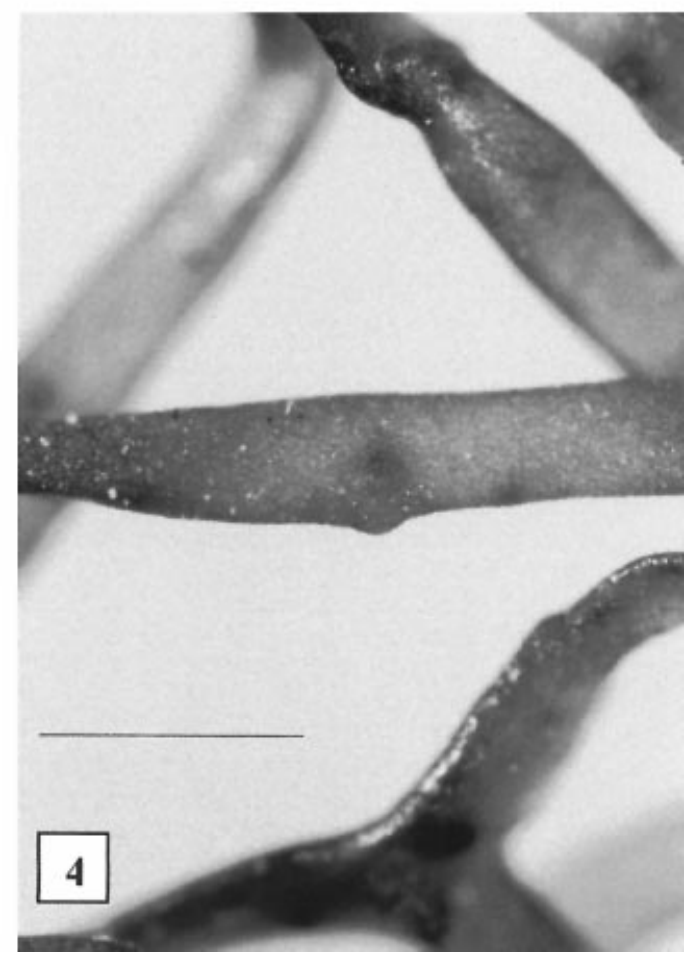

Figs 1-4. New algal records from the Azores.

Fig. 1. Laminaria ochroleuca, habit photograph (scale in $\mathrm{mm}$ and $\mathrm{cm}$ ). Fig. 2. Dudresnaya crassa, habit photograph (scale in $\mathrm{mm}$ and $\mathrm{cm}$ ). Fig. 3. Pterosiphonia ardreana, portion of frond showing branching and linear shape $(\mathrm{scale}$ bar $=500 \mu \mathrm{m})$. Fig. 4. Ahnfeltiopsis c. f. intermedia, portion of frond showing immersed cystocarp (scale bar $=500 \mu \mathrm{m})$. 
This record is from material in BM. The species is probably an intertidal turf-forming plant, sporadic in occurrence (not recently recorded).

Ahnfeltiopsis intermedia was first described from South Africa and subsequently found in Nigeria and the Ivory Coast (Lawson and John 1987). An Azorean record would represent a northern extension of its distributional range.

Specimens examined: Faial I., Chelsea College Expedition, 06. 8. 1965, 110 (BM).

\section{Rhodymeniales, Champiaceae}

\section{Lomentaria clavellosa (Turner) Gaillon}

Full description and illustration in Irvine and Guiry 1983, p. 87, fig. 26.

Azorean plants are small ( $5 \mathrm{~mm}$ high) and consist of a main axis with a few lateral branches. Thalli are multi-axial, and medullary filaments form a network clearly visible through the cortex. Fertile material has not been found.

The species grew at sublittoral levels $(3-9 \mathrm{~m}$ depth) and was epilithic and epiphytic on larger algae. It occurred only rarely.

Lomentaria clavellosa is a widespread, amphi-Atlantic species (Iceland to Morocco, Nova Scotia to Connecticut) and also occurs in the Mediterranean Sea.

Specimens examined: São Miguel I., São Vicente, 19. 07. 1996, SMG-96-304 (UA); São Miguel I., São Vicente, 15. 07. 1997, SMG-97-114a (UA); São Miguel I., Lagoa 18. 07. 1997, SMG-97-192 (UA).

\section{Ceramiales, Delesseriaceae}

\section{Cottoniella filamentosa (Howe) Børgesen}

Full descriptions and illustrations in Howe 1905, p. 571 , pl. 29, figs. 1-11, and Cormaci et al. 1978, p. 251, figs. $1-14$.

Occurs as an iridescent, bluish-pink, delicate filamentous plant that grows to $50 \mathrm{~mm}$ high. Thalli comprise filaments of five pericentral cells surrounding a central axial row of cells. Uniseriate lateral branches arise in pairs from one side of the main axis. Tetrasporangia occur in parallel rows in dorsi-ventral, stichidia-like lateral branches.

The species occurred at sub-littoral levels (to $30 \mathrm{~m}$ ) and formed patches on rocks. It also grew as tufts on larger algae.

Cottoniella filamentosa is an amphi-Atlantic, warm-water species which was described from Florida and subsequently recorded in the eastern Atlantic Ocean from southern Spain, Madeira, the Canary Islands, the Cape Verde Islands and Mauritania as well as the Mediterranean Sea.

Specimens examined: São Miguel I., São Vicente, 16. 07. 1996, SMG-96-206 (UA); São Miguel I., São Vicente, 11. 07. 1997, SMG-97-15 (UA); São Miguel I., São Vicente, 21. 07. 1997, SMG-97-239 (UA); São
Miguel I., Ribeirinha, 22. 07. 1997, SMG-97-328 (UA); São Miguel I., Lagoa, 18. 07. 1998, SMG-97194 (UA).

\section{Dasyaceae}

\section{Dasya baillouviana (S. Gmelin) Montagne}

Full description and illustration in Taylor 1957, p. 326 , pl. 54, figs. $1-4$, and 1961, p. 562, [as D. pedicellata (C. Agardh) C. Agardh].

Only small solitary plants (to $20 \mathrm{~mm}$ high) were found in the Azores. The species is plumose in appearance with a solid, heavily corticated main axis that gives rise to lateral branches distally. These laterals are corticated at the base and bear dichotomously branched uniseriate filaments towards the apex. Fertile material has not been observed in the Azores.

The species occurred rarely at sub-littoral levels (to $20 \mathrm{~m}$ depth) among an algal turf.

Dasya baillouviana is an amphi-Atlantic species which is widespread along American coasts (from the Caribbean to Nova Scotia and Prince Edward Island) and common in Bermuda. It occurs in the eastern Atlantic Ocean in Ghana, Canary Islands and Madeira, and has relatively recently spread to the Netherlands, the eastern Baltic and southern Norway. The species is also known from the Mediterranean Sea.

Specimens examined: São Miguel I., São Vicente, 11. 09. 1997, SMG-97-17 (UA).

\section{Heterosiphonia crispella (C. Agardh) Wynne}

Full descriptions and illustrations in Taylor 1961, p. 565, pl. 72, fig. 9 (as H. wurdemanni), and in Lawson and John 1987, p. 288, pl. 48, fig. 3.

Synonym: Heterosiphonia wurdemanni (J. Bailey ex Harvey) Falkenberg.

Azorean plants consist of filamentous tufts to $20 \mathrm{~mm}$ high. Filaments are dichotomously or irregularly branched and arise from a prostrate system. The main axial filament has six pericentral cells and bears distally incurved monosiphonous laterals attached to alternate segments. These laterals are dichotomously or alternately branched two to four times. Fertile plants have not been seen in the Azores.

The species occurred only occasionally on Codium elisabethae at sublittoral levels (to $10 \mathrm{~m}$ depth) and is known only from São Miguel Island (the source of the record for the Azores in South and Tittley (1986) has not been confirmed).

Heterosiphonia crispella is an amphi-Atlantic warm-water species occurring in the Caribbean and Florida in the western Atlantic Ocean, Bermuda, the Azores, and widely in the south-eastern North Atlantic from southern Spain (type locality Cadiz), Morocco, Canary Islands, Cape Verde Islands to Mauritania, tropical Africa and Ascension Island. It also occurs in the Mediterranean Sea. 
Specimens examined: São Miguel I., São Vicente, 16. 09. 1998, SMG-98-1184 (UA); São Miguel I., Lagoa, 18. 09. 1998, SMG-98-1197 (UA).

Rhodomelaceae

\section{Pterosiphonia ardreana Maggs et Hommersand}

See Maggs and Hommersand 1993, p. 369, fig. 115 for full description and illustration.

It is a small tufted plant, which grows to $30 \mathrm{~mm}$ high in algal turf. It has an erect axis, which arises from a prostrate system, and bears a complanate, alternate-distichous arrangement of short lateral branches, giving a linear-lanceolate outline to the thallus. All axes are ecorticate, and the main axis has 10-12 pericentral cells (Fig. 3). Fertile material has not been observed in the Azores.

The species grew at sublittoral levels (to $10 \mathrm{~m}$ depth).

Pterosiphonia ardreana is known only from southwest England, Ireland, France, Portugal, the Mediterranean and now also from the Azores.

Specimens examined: São Miguel I., São Vicente, 16. 09. 1998, SMG-98-1187 (UA).

\section{Discussion}

Most of the algae reported here are diminutive species or diminutive specimens of elsewhere larger species that occurred sub-tidally in the algal turf on rocks and boulders. Others were small epiphytes on larger species. Many were found in a sterile state, although Ahnfeltiopsis c.f. intermedia and Bonnemaisonia asparagoides were cystocarpic and Cottoniella filamentosa bore abundant tetrasporangia. Further fieldwork at other times of the year may reveal reproductive material.

Laminaria ochroleuca is much larger than the other species mentioned here but nonetheless specimens collected in the Azores were small compared with plants from southern Britain, France and Iberia. A major difference in algal community structure in the Azores compared with northern Europe is the near absence of canopy forming large brown algae over intertidal and subtidal seashores (Fucus spiralis Linnaeus occurs patchily on upper midlittoral rocks). Laminaria ochroleuca has been detected only as a single population in very deep water on the isolated Formigas Islets located $38 \mathrm{~km}$ southeast of São Miguel.

The occurrence in the Azores of six species (Bryopsis pennata, Cottoniella filamentosa, Dasya baillouviana, Feldmannia paradoxa, Heterosiphonia crispella

\section{References}

Athanasiadis, A. and I. Tittley. 1994. Antithamnioid algae (Rhodophyta, Ceramiaceae) newly recorded from the Azores. Phycologia 33: 77-80. and Lomentaria clavellosa) of the twelve listed fits with their known amphi-Atlantic distribution. Three (Bryopsis pennata, Cottoniella filamentosa, Heterosiphonia crispella) are warm-water species restricted in distribution to southern Europe, Africa or Macronesia, while Dasya baillouviana and Feldmannia paradoxa also occur further north (Canada, southern Scandinavia, northern Scotland). Lomentaria clavellosa is widespread in both cold-temperate (Nova Scotia to Connecticut, Iceland, Scandinavia, Britain) and warm-temperate waters. Dudresnaya crassa is a warm-water western Atlantic species found for the first time in the mid-Atlantic Ocean but not in the east on mainland Europe and Africa. Four of the records (Bonnemaisonia asparagoides, Laminaria ochroleuca, Pterosiphonia ardreana and Stylonema cornucervicoris) are species restricted in distributional range to the eastern Atlantic Ocean (Britain to Portugal, the Mediterranean Sea, Africa and Macronesia); their occurrence in the Azores represents the western limit of distribution. Ahnfeltiopsis intermedia is known only to the south of the Azores.

The checklist and distributional index of the benthic marine algae of the North Atlantic Ocean (South and Tittley 1986) listed 186 species for the Azores. The decade of research activity since then has increased the total to 360 . We envisage further additions as difficult material of the orders Corallinales and Ceramiales is determined. Material of Botryocladia, Cryptonemia, Dudresnaya, Platoma and Predaea is currently undergoing investigation and is also likely to yield additions to the flora. A small component has been incorrectly identified and records such as Dilsea carnosa (Schmidel) Kuntze and Coccotylus truncata (Pallas) M. Wynne et J. Heine should be removed from the flora.

\section{Acknowledgements}

The results presented in this paper are part of the JNICT funded project 'Praxis XXI - Biodiversity of the Azores Archipelago (2/2.1/BIA/169/94)'. The European Union TMR supported a study visit by AIN to the NHM. Sandra Monteiro is thanked for her considerable help and Drs W. F. Prud'homme van Reine and R. Haroun are thanked for valuable discussions. We also acknowledge the Director and staff of the National Herbarium of the Netherlands, Leiden, for access to herbarium collections and library facilities.

Accepted 28 December 2000.

Cardinal, A. 1964. Etude sur les Ectorpacées de la Manche. Beih. Nova Hedwigia 15: 1-86. 
Cormaci, M., G. Furnari and B. Scammaca. 1978. On the fertile tetrasporic phase of Cottoniella Børgesen (Ceramiales, Rhodomelaceae, Sarcomenioideae). Phycologia 17: $252-256$.

Dixon, P. S. and L. M. Irvine. 1977. Seaweeds of the British Isles. Volume 1 Rhodophyta. Part 1 Introduction, Nemaliales, Gigartinales. British Museum (Natural History), London, $\mathrm{xi}+251 \mathrm{pp}$.

Eiseman, N. J. and J. N. Norris. 1981. Dudresnaya patula sp. nov. an unusual deep-water red alga from Florida. J. Phycol. 17: 186-191.

Fralick, R. A. and E. J. Hehre. 1990. Observations on the marine algal flora of the Azores II. An annotated check list of the Chlorophyta of the Azores. Arquipélago (Life and Earth Sciences) 8: 11-17.

Fredericq, S., E. Serrão and J. Norris. 1992. New records of marine red algae from the Azores. Arquipélago (Life and Earth Sciences) 10: 1-4.

Hamel, G., 1924. Floridées de France. Rev. algol. 1: 427457.

Hamel, G. 1931-1939. Phéophycées de France. Paris. XLVII + $431 \mathrm{pp}$.

Howe, M. A. 1905. Phycological Studies II. New Chlorophyceae, new Rhodophyceae, and miscellaneous notes. Bull. Torrey bot. Club 32: 563-586.

Irvine, L. M. and M. D. Guiry. 1983. Rhodymeniales. In: (L. M. Irvine), Seaweeds of the British Isles. Volume 1 Rhodophyta. Part 2A Cryptonemiales (sensu stricto), Palmariales, Rhodymeniales. British Museum (Natural History), London, pp. 77-98.

Lamouroux, J. V. F. 1809. Memoire sur les Caulerpes, nouveau genre de la famille des Algues marines. J. Bot. Paris 2: 136-146.

Lawson, G. W. and D. M. John. 1987. The marine algae and coastal environmental of tropical West Africa (Second edition). Beih. Nova Hedwigia 93: i-vi + 1-415.

Maggs, C. H. and M. A. Hommersand. 1993. Seaweeds of the British Isles. Volume I Rhodophyta. Part 3 A Ceramiales. The Natural History Museum, London. Xv + $444 \mathrm{pp}$.
Neto, A. I. 1992. Contribution to the taxonomy and ecology of Azorean benthic marine algae. Biol. J. Linn. Soc. 46: $163-176$.

Neto, A. I. 1994. Checklist of the benthic marine algae of the Azores. Arquipélago (Life and Marine Sciences) 12A: $15-24$.

Neto, A. I. and I. Tittley. 1995. Structure and zonation of algal turf communities on the Azores: a numerical approach. Bolm. Mus. Munic. Funchal Sup. No. 4: 487504.

Parente, M. I. and A. I. Neto. 2000. New records of benthic marine red algae (Ceramiales: Rhodophyta) from the Azores. Arquipélago (Life and Marine Sciences) Sup. 2 (Part A): 53-61.

Schneider, C. W. and R. B. Searles. 1973. North Carolina marine algae. II. New records and observations of the benthic offshore flora. Phycologia 12: 201-210.

South, G. R. and I. Tittley. 1986. A Checklist and Distributional Index of the Benthic Marine Algae of the North Atlantic Ocean. Huntsman Marine Laboratory and British Museum (Natural History). St. Andrews and London. $78 \mathrm{pp}$.

Stegenga, H., J. Bolton and R. J. Anderson. 1997. Seaweeds of the South African West Coast. Contributions from the Bolus Herbarium Number 18. University of Cape Town, Cape Town. 655 pp.

Taylor, W. R. 1957. Marine Algae of the Northeastern Coast of North America. University of Michigan Press, Ann Arbor. ix +509 pp.

Taylor, W. R. 1960. Marine Algae of the Eastern Tropical and Subtropical Coasts of the Americas. University of Michigan Press, Ann Arbor. xi +870 pp.

Taylor, W. R. 1961. Notes on three Bermudan algae. Hydrobiologia 18: 277-283.

Tittley, I. and A. I. Neto. 1994. "Expedition Azores 1989". Benthic marine algae (seaweeds) from Faial and Pico. Arquipélago (Life and Marine Sciences) 12A: 1-13.

Tittley, I. and A. I. Neto. 1995. The marine algal flora of the Azores and its biogeographical affinities. Bolm. Mus. Munic. Funchal Sup. no. 4: 747-766.

Tittley, I., A. I. Neto and W. F. Farnham. 1998. Marine algae of the Island of Flores, Azores: ecology and floristics. Bolm. Mus. Munic. Funchal Sup. no. 5: 463-479. 
Copyright of Botanica Marina is the property of Walter de Gruyter \& Co. and its content may not be copied or emailed to multiple sites or posted to a listserv without the copyright holder's express written permission. However, users may print, download, or email articles for individual use. 